Review Article

\title{
Governments' Policy Response to Drought in Eswatini and Lesotho: A Systematic Review of the Characteristics, Comprehensiveness, and Quality of Existing Policies to Improve Community Resilience to Drought Hazards
}

\author{
Joseph K. Kamara $\left(\mathbb{D},{ }^{1,2}\right.$ Berhe W. Sahle, ${ }^{1}$ Kingsley E. Agho,, \\ and Andre M. N. Renzaho ${ }_{(D)}^{1,5,6}$ \\ ${ }^{1}$ School of Social Sciences, Western Sydney University, Penrith 2751, Australia \\ ${ }^{2}$ World Vision International, Southern Africa Regional Office, Mbabane H-100, Eswatini \\ ${ }^{3}$ School of Health Sciences, Western Sydney University, Penrith 2751, Australia \\ ${ }^{4}$ African Vision Research Institute (AVRI), University of KwaZulu-Natal, Durban 4041, South Africa \\ ${ }^{5}$ Translational Health Research Institute, Western Sydney University, Penrith 2751, Australia \\ ${ }^{6}$ Maternal, Child and Adolescent Health Program, Burnet Institute, Melbourne 3004, Australia \\ Correspondence should be addressed to Joseph K. Kamara; j.kamara@westernsydney.edu.au
}

Received 26 August 2019; Revised 3 December 2019; Accepted 18 January 2020; Published 26 February 2020

Academic Editor: Paolo Renna

Copyright ( 2020 Joseph K. Kamara et al. This is an open access article distributed under the Creative Commons Attribution License, which permits unrestricted use, distribution, and reproduction in any medium, provided the original work is properly cited.

\begin{abstract}
The southern African kingdoms of Eswatini and Lesotho experience recurrent drought-induced disasters. Policies have been enacted, but no attempt has been made to synthesise the effects on disaster resilience. This review analyses the characteristics, quality, and comprehensiveness of drought-resilience policies in Eswatini and Lesotho. We have systematically reviewed public policies that shape responses to disaster resilience published between 1 January 1980 and 30 June 2019. A combination of keywords was used to search electronic bibliographic databases, multidisciplinary databases, key organisational websites, and the first 20 pages of Google for policies that addressed disaster and/or drought resilience. Identified documents were downloaded into an EndNote database and screened for eligibility using predetermined criteria. The logic of events framework was used for quality assessment, and a metaethnographic approach was applied for data synthesis. Three broad categories of characteristics, thematic outcomes and quality, and comprehensiveness of policy documents emerged and are presented. Policy responses contributing to disaster resilience were found in $n=32$ out of 13,700 documents. Three ( $n=3$ / $32)$ policies were statutory, and the rest were nonstatutory. Eleven $(n=11 / 32)$ were assessed to be of high quality. Policy responses relating to drought resilience focused on reducing vulnerability to recurrent disasters; promoting drought and climate change adaptation; improving agriculture and food security; safeguarding cultural heritage; and preventing gender inequality and gender-based violence as well as improving disaster governance. However, the construct of drought resilience was not strongly articulated as a major policy goal across policy documents. There is an urgent need to promote better understanding of drought resilience in order to motivate policymakers to steer away from reactive interventions and position resilience as a major national policy goal in both countries to expedite inclusive growth and safeguard development gains and the health and wellbeing of the majority of their populations who are rural-based populations.
\end{abstract}

\section{Introduction}

Southern Africa experiences catastrophic recurrent environmental hazards such as drought, cyclones, and floods due to the changing climate [1]. Climate-induced hazards have continuously eroded development gains and livelihoods, disrupted societal routines, and affected human health and wellbeing $[2,3]$. The last three decades have seen significant increases in climate-induced hazards such as drought occurrences which have become longer and severely exacerbated poor agricultural outputs, livestock losses, and poor health and wellbeing [3-6]. The governments in the region 
have responded with various policy instruments to address the threat of recurrent drought. Nonetheless, recurrent droughts remain the most pernicious of all environmental hazards, often affecting large populations over an extended period and geographical area [7].

Drought is commonly defined as a paucity of precipitation resulting in water shortage over an extended period of time in a particular geographical area [8-10]. The drought phenomenon can be classified under the four major categories of socioeconomic, meteorological, agricultural, and hydrological droughts, and the classification depends on how it is experienced. Socioeconomic drought occurs when the demand for goods and services exceeds the supply due to unfavourable climatic conditions causing water shortage over a given period. For example, when the demand for electricity exceeds its supply due to reduced electricity generation because of a fall in water levels in dams, the situation can be termed a socioeconomic drought. Meteorological drought refers to below-normal precipitation for over a season or more when it is expected, leading to significant decline in water reservoirs; agricultural drought occurs when meteorological drought negatively affects crops and agricultural production in a given geographical area; and lastly, hydrological drought is when below-normal precipitation causes surface reservoirs and below-surface aquifers to dwindle or desiccate $[8,10]$.

This study is concerned with polices addressing any or all the droughts described above which cause significant socioeconomic, cultural, and health impacts. Economically, recurrent drought weakens the region's economies and erodes development gains. Evidence suggests significant reductions of up to $9 \%$ of GDP and increases in household poverty levels during drought occurrences across the region's economies [11, 12]. Furthermore, drought negatively impacts national development plans when resources are channelled to drought emergency interventions and it has been identified as one of the hamstrings of GDP per capita growth in sub-Saharan Africa [12, 13].

Culturally, recurrent and sustained droughts have been associated with the erosion of collective norms and cultures in favour of individually based survival strategies [14]. Oviawe [15] observed that aggressive competition for resources in times of adversity when demand for resources exceeded supply led to weakening of the long-held collective traditions of inclusiveness in Namibia. In terms of health, droughts cause poor health outcomes particularly because drought curtails the availability of locally produced food such as grains, pulses, and vegetables which are some of the main sources of nutrition among rural subsistence populations. The vast proportion of sub-Saharan African populations especially in rural areas relies on their locally produced food. Evidence points to drought reducing health outcomes through inadequate food consumption and associated diseases and exposing infants and unborn children to malnutrition-related risks [16-18]. Hoddinott and Kinsey [19] observed that children aged 12 to 24 months lost 1.5 to 2 centimetres of growth after a drought occurrence in Zimbabwe. Similarly, Lazzaroni and Wagner [20] observed that drought and the associated food price increases were responsible for up to $24 \%$ and $43 \%$ of the standard deviations, respectively, in child weight-for-age in rural Senegal. De Waal and colleagues [21] compared child mortality in drought- and non-drought-affected rural areas of Ethiopia and found high child mortality $(109 / 10,000)$ in droughtaffected rural areas compared to $86 / 1000$ children in nondrought-affected rural areas. Additionally, early childhood exposure to drought and malnutrition has lifelong impacts such as growth impedance, disability, and lower quality of life outcomes [22, 23].

Nonetheless, southern African countries are affected by recurrent drought differently based on their resilience capacity. This is reflected in each country's policies and choice of response actions; for example, not all countries in the region declare national disaster emergencies and/or appeal for international aid during drought occurrences $[24,25]$. This suggests the existence of effective policy interventions that have progressed from reactive crisis intervention to strategically building resilience to drought [26]. However, the countries that frequently declare drought disaster emergencies and/or appeal for aid implement reactive disaster management strategies [27]. While appeals for aid do not equate to the actual commitments and aid received, the appeals are an indicator of government policy on tackling recurrent drought. Evidence (see Table 1) suggests that since the early 1980s, drought occurrences have exponentially increased across the southern African region, followed by aid appeals to mitigate the drought effects [24, 25, 28, 29].

Policy can be broadly categorised into hard and soft categories. Torenvlied and Akkerman [34] argued that hard policies are statutorily binding decisions consisting of compulsory requirements. Hard policies emerge out of regulatory and legislative processes and carry the threat of sanction for noncompliance. The authors further argued that soft policies are voluntary, nonbinding decisions and recommendations based on appeal and attraction emerging from multilevel systems of government that require alternative approaches other than legislation and regulation. We argue that policy is about the power to keep society focused on collectively desired aspirations. In this context, the term "power" denotes a form of relationship between partners and/or a way in which certain actions modify others. Foucault's theory of power suggests that power relations in societies are informed by culturally engendered notions and that these notions can be accepted or contested [35]. The theory further asserts that societies are guided by notions that shape behaviour and such notions constitute policy discourses moderated by social interactions $[35,36]$. However, the discursive interaction of policy moderation is held by society's powerbrokers, who maintain a grip on the process to sustain the power balance in favour of the prevailing political interests [35, 37, 38]. The powerbrokers must convince their societies to accept a policy by making it relevant to society's needs, realistic and reflective of collective values and aspirations, and flexible enough to accommodate the changes in an evolving society [37, 39]. These elements are reflected through solicitation of ideas from stakeholders in order to make a policy inclusive. 
TABLE 1: Regional selected humanitarian appeals for drought emergency response.

\begin{tabular}{|c|c|c|c|c|c|c|}
\hline Country & Botswana & Eswatini & Lesotho & Namibia & South Africa & Ref. \\
\hline $\begin{array}{l}\text { Drought period 1992-93 } \\
\text { Population in need of assistance in million (\%) } \\
\text { Appeal USD million }\end{array}$ & $\begin{array}{l}0.1(33.1 \%) \\
5.73\end{array}$ & $\begin{array}{c}0.25(21.2 \%) \\
16.2\end{array}$ & $\begin{array}{c}0.17(28 \%) \\
11.1\end{array}$ & $\begin{array}{c}0.25(35.2 \%) \\
19.4\end{array}$ & $\begin{array}{l}00 \\
00\end{array}$ & [30-32] \\
\hline $\begin{array}{l}\text { Drought period 2012-13 } \\
\text { Population in need of assistance in million (\%) } \\
\text { Appeal USD million } \\
\text { Drought period 2015-17 }\end{array}$ & $\begin{array}{l}00 \\
00\end{array}$ & $\begin{array}{c}0.3(28 \%) \\
11.3\end{array}$ & $\begin{array}{c}0.76(34 \%) \\
5.5\end{array}$ & $\begin{array}{l}00 \\
00\end{array}$ & $\begin{array}{l}00 \\
00\end{array}$ & {$[13,24]$} \\
\hline $\begin{array}{l}\text { Population in need of assistance in million (\%) } \\
\text { Appeal USD million }\end{array}$ & $\begin{array}{c}0.057(1.1 \%) \\
00\end{array}$ & $\begin{array}{l}0.64(72 \%) \\
92\end{array}$ & $\begin{array}{l}0.71(14.2 \%) \\
38\end{array}$ & $\begin{array}{l}0.72(15.4 \%) \\
56.6\end{array}$ & $\begin{array}{c}14.3(8.0 \%) \\
00\end{array}$ & {$[24,32,33]$} \\
\hline
\end{tabular}

Furthermore, the construct of power is continuously exercised when the policy is approved by an authority [39].

At the community level, where the recurrent droughtinduced disasters' effects are most experienced, different coping and adaptation capacities exist. These capacities vary between communities and manifest as common shared values, experiences, connectedness, collective responses, and the ability to learn and share knowledge to overcome adversity [40]. The level of community capacity depends on its ability to harness the prevailing resources and on policies that aid collective responses to reduce the effects of recurrent drought. Foucault [35] argued that social interactions inform knowledgeability and influence power relations. $\mathrm{He}$ further argued that the balance of power relations resides in a symbiotic duality of recognition and/or maintenance of those over whom power is exercised throughout a process and that the exercise of a power induces reactions that produce the desired change. In the context of our study, the desired change is community resilience to recurrent drought hazards.

This study examines policy responses in Eswatini and Lesotho. The two countries were chosen based on many aspects. They have historically experienced periodic drought exposures that overwhelm local capacities, resulting in national disasters [2]. The most intense occurrences with disastrous effects were recorded in 1981-84, 1990-92, 2001-03, 2006-08, 2011-13, 2015-16, and 2018-19 [2, 41-45]. Eswatini and Lesotho have similarities in disaster governance approaches and similar geographical, climatological, social-cultural, and political characteristics. In terms of governance, the two countries have similar disaster governance mechanisms spearheaded by their Disaster Management Agencies (DMAs). The DMAs are constitutionally mandated to oversee all aspects of disaster mitigation and management. The DMAs were established in 1997 and 2006 in Lesotho and Eswatini, respectively, and became centres for coordination of disaster responses including drought-induced disaster response interventions.

However, the coordination of policies in relation to the environment, climate change, poverty, and inequality, which correlate with drought vulnerability, has oscillated between different government bodies. For example, in Eswatini, the first national communication to the United Nations Framework for Convention on Climate Change (UNFCC) was prepared by the Ministry for Public Works and Transport, while the second and third communications to the UNFCC and the climate change policy were prepared by the Ministry of Tourism and Environmental Affairs. In Lesotho, the communications to the UNFCC and the climate change policy were prepared by the Ministry of Natural Resources and Ministry of Energy and Meteorology. The absence of an appropriate agency to coordinate all droughtrelated interventions remains a critical gap in drought governance in both countries.

Geographically, Eswatini and Lesotho are mountainous and landlocked countries, with Lesotho being an enclaved country within the border of South Africa, while Eswatini is surrounded by South Africa and Mozambique. Lesotho is mostly a highland country with a highest elevation of 3482 and a lowest elevation of 1400 metres above sea level and has four agroecological zones, highlands, foothills, lowlands, and the Senqu River valley, which forms the lowest elevation and is an extension of the lowlands [46]. Similarly, Eswatini has four agroecological zones, highlands, foothills, lowlands, and the Lubombo plateau. The country has a highest elevation of 1862 and a lowest elevation of 21 metres above sea level in the Great Usutu River valley [47].

In terms of climate, Eswatini oscillates between tropical and temperate with temperatures ranging from $-3^{\circ} \mathrm{C}$ in winter to $42^{\circ} \mathrm{C}$ in summer [48]. Lesotho's climate is mainly temperate with temperatures from $-7^{\circ} \mathrm{C}$ in winter to $30^{\circ} \mathrm{C}$ in summer [48]. Socioculturally, both countries are homogeneous with ethnolinguistic structures of 99.7\% Basotho (Lesotho) and 87.3\% Swazi (Eswatini) [49-51]. Politically, the two countries are monarchies. Eswatini remains an absolute monarchy, while Lesotho blends monarchism with a parliamentary constitution [40].

All of these characteristics make studying resilience policies across the two countries compelling. Furthermore, the governments of Eswatini and Lesotho recognise the importance of drought resilience as a necessity for sustainable development, which they both committed to under the United Nations Sustainable Development Goals (SDGs) $[52,53]$. Four of the 17 SDGs are interlinked with drought resilience. These are Goal 2, which seeks to end hunger and achieve food and nutrition security; Goal 11, aiming to make human settlements safe and resilient; Goal 13, addressing climate change and its impacts; and Goal 15, which promotes sustainable living and combating desertification and land and biodiversity degradation [54]. Therefore, it is important to assess the two governments' performance against their commitments to their populations and the 
international community. One way to assess these governments' progress against their commitments is by systematically reviewing existing policies which mirror society's views and provide interpretation of the procedural paradigms [55]. So far, no attempt has been made to systematically review the characteristics, comprehensiveness, and quality of such policies and their effects on the governments' commitment to community drought resilience. Therefore, the aim of this systematic review is to analyse the characteristics, quality, and comprehensiveness of community resilience policies in Eswatini and Lesotho. The findings of this review will provide information and knowledge necessary for a paradigm shift away from reactive governance strategies towards sustainable disaster resilience. This systematic review focuses on the existing policy instruments and how they enable drought resilience among the rural farming communities of Eswatini and Lesotho. The review does not evaluate the effectiveness of policy formulation and implementation processes or policy effectiveness, which are beyond the scope of the study purpose. However, it reports a metaethnographic study addressing the question: How do the policies and regulatory frameworks of Eswatini and Lesotho stimulate drought resilience?

\section{Materials and Methods}

2.1. Operational Definitions. Policy is complex and has been widely explored by various scholars; however, it remains without a universally agreed-upon definition that transcends the different contexts. Policy scholars wrestle with the choice of language to frame their definitions commensurate with their study purpose. The Centers for Disease Control and Prevention (CDC) [56] defined policy as a law, regulation, procedure, administrative action, incentive or voluntary practice of governments and other institutions (pg.1). This study adopted the CDC broad definition to enable detailed examination of all intents and actions embedded in government documents such as statutory acts, strategies, systems of principles, guidelines, action plans, and reports on goals and commitments with a stated focus on disaster resilience. Additionally, a strategy is a comprehensive master plan designed to respond to a dynamic and challenging environment in pursuit of a major goal [57]. For the purpose of this study, we categorise all documents capturing governments' intentions and actions towards building and strengthening resilience as policy documents. This broad approach to policy is consistent with the study purpose and has been previously applied in policy studies $[58,59]$.

Policy guides action on government intent towards the desired goal and is operationalised through policy action, that is, the output serving the purpose of meeting the policy goal [60]. Some studies suggest that while a policy action may be designed to address a single goal, it will often affect multiple policy outcomes $[57,60]$. Furthermore, a policy response is a discourse between policymakers who frame a policy goal and those who implement the policy. Policy studies argue that this discourse between policymakers and implementers contains the three critical domains of problem-solving, process, and theoretical eclecticism $[38,61]$.
Problem-solving is where policymakers provide a policy to the implementers to interpret and operationalise; the process domain is the cocreation of outcomes by policymakers and implementers through the contesting of ideas, negotiation, and revision to fine-tune a policy; and theoretical eclecticism refers to the use of language and the exercise of power to legitimise a policy enriched by the problem-solving and process domains [38]. These domains underpin policy responses in mature as well as growing democracies such as Eswatini and Lesotho.

2.2. Search Strategy. We systematically searched electronic bibliographic databases and key organisational websites for policy documents published between 1 January 1980 and 30 June 2019. The following key search terms were used alongside subject heading truncations $(*)$ and Boolean operators:

(Disaster * OR hazard * OR drought *) AND (resilien * OR adapt $*$ OR coping OR adjustmen * OR coheren *) AND (policy $O R$ Policie $* O R$ rule $* O R$ regulation $* O R$ guideline $* O R$ convention * OR method $*$ OR model $*$ OR framework *) AND (Lesotho OR Swaziland OR Eswatini).

These search terms were developed in collaboration with a librarian experienced in systematic reviews. We searched in the following bibliographic databases: EBSCOhost, ProQuest, Scopus, and Web of Science. The search in the bibliographic databases was complemented by searches of the African journals that specifically capture southern African literature; these journals were African Journals On Line (AJOL) and Sabinet African Journals (journals.co.za). The search terms were adjusted based on the database or journal requirements. Recognising that some literature related to policy may not be peer-reviewed; we also searched the first 20 pages of Google for grey literature. This was complemented by searches of the following multidisciplinary databases and key websites: African Development Bank, United Nations Framework Convention on Climate Change, ReliefWeb, United Nations International Strategy for Disaster Risk Reduction (UNISDR), Food and Agricultural Organization (FAO), Southern African Development Community (SADC), Eswatini Government (http:// www.gov.sz), Lesotho Government (http://www.gov.ls), PreventionWeb, African Climate Voices, and Organisation for Economic Co-operation and Development (OECD). Furthermore, we sought information and unpublished documents from subject matter experts.

2.3. Study Participants. The study scope necessitated coverage of the general populations of Lesotho and Swaziland, mainly because regulatory frameworks and policies apply across the two countries' populations.

2.4. Inclusion and Exclusion Criteria. Based on our definition of policy, we included a broad range of policy documents (see Table 2). The included policy documents were published after 1 January 1980, when drought frequency and intensity increased alongside emergency drought appeals for 
TABLE 2: Inclusion and exclusion criteria.

\begin{tabular}{lc}
\hline Included & Excluded \\
\hline $\begin{array}{l}\text { Government documents such as policies and policy reports, action } \\
\text { plans, development plans, drought response plans, strategies, and acts } \\
\text { of parliament that relate to disaster resilience }\end{array}$ & \begin{tabular}{l} 
Government documents that do not relate to the subject \\
\hline $\begin{array}{l}\text { Documents approved by a government entity } \\
\text { Documents published after 1 January 1980 }\end{array}$
\end{tabular} \\
\hline $\begin{array}{c}\text { Unapproved documents or those approved by nongovernment } \\
\text { entities and/or not approved on behalf of government }\end{array}$ \\
\hline $\begin{array}{l}\text { Documents not classified as government secrets } \\
\text { Documents from Lesotho or Eswatini }\end{array}$ & $\begin{array}{c}\text { Government-classified documents } \\
\text { Lesotho and Eswatini }\end{array}$ \\
\hline Both peer- and nonpeer-reviewed literature & $\begin{array}{c}\text { Reviews, editorials, letters to editors, opinion pieces, and } \\
\text { protocols }\end{array}$ \\
\hline Full text available and accessible & Inaccessible policies \\
\hline
\end{tabular}

international assistance $[6,25]$. Table 2 presents our broad inclusion and exclusion criteria.

The reference lists of the included policy documents were also read, and relevant documents were identified from these reference lists and included in our review. Additionally, subject matter experts were contacted for reference to any other relevant policy documents that address disaster resilience. A search log capturing all activities relating to literature searching, screening, inclusion, and exclusion was maintained for transparency.

2.5. Data Extraction. The principal researcher (JKK) extracted data from databases and websites into an EndNote library using a piloted form. The extracted data comprised policy contexts such as author, date, country, policy category, target group, and policy focus (see Table 3 ). The second researcher (BWS) reviewed the extracted data and sampled the databases and websites with the same search terms used by the first author to test whether the extracted data matched what was available in the databases. Differences were discussed and common ground reached.

2.6. Document Screening and Selection. The eligibility of policy documents was determined following a three-stage screening process consistent with the Cochrane guidelines for screening of studies in systematic reviews [91]. Firstly, policies were screened by title to eliminate duplication. Secondly, the remaining documents' abstracts, preambles, and/or introduction sections were read for their relevance to the study purpose. Thirdly, the retained policy documents were read in full to determine their eligibility and those that met our criteria were retained for inclusion (see Figure 1). The principal reviewer undertook the above process while maintaining a record of all actions undertaken. The record was shared with the second reviewer as a basis for verification. Emerging discrepancies were discussed and resolved by consensus. For example, the second reviewer disputed the exclusion of two documents. This led to reexamination and discussion of the documents in question until the reviewers agreed that the documents were still in draft form and had not been approved by a government entity which justified their exclusion as per the inclusion and exclusion criteria (see Table 2).

2.7. Quality Assessment. Policies officially approved by a recognised government entity, whether peer-reviewed or not, were included in the study. The most commonly used quality assessment framework for grey literature is the Authority, Accuracy, Coverage, Objectivity, Date, Significance (AACODS) $[29,92,93]$. However, we found the AACODS framework inappropriate for the quality assessment of policy documents. Thus, we applied von Wright's logic of events framework for quality assessment [94]. The logic of events framework was specifically developed to assess policy documents; it was validated by Rutten and colleagues and subsequently adapted by Cheung and colleagues $[95,96]$. The adopted framework has seven domains that address policy accessibility $(n=1$ item), policy background ( $n=4$ items), policy goals $(n=6$ items), resources ( $n=3$ items), monitoring and evaluation ( $n=7$ items), public opportunities ( $n=2$ items), and obligations ( $n=2$ items), resulting in a total of 25 items. The items were each scored with a yes ( 1 point) or no ( 0 points), giving a possible score range from 0 to 25 .

Two authors (JKK and BWS) independently rated the included policy documents for quality. Tertiles were used to split the data into three groups: $1=$ insufficiently developed $(0 / 16=1) ; 2=$ moderately developed $(16.01 / 19=2) ;$ and 3 = robustly developed $(19.01 / 25=3)$ (Table 3$)$. Cohen's kappa statistic was used to assess the agreement on scoring and ranking of the policy documents and this was 0.72 $(p<0.001)$, hence indicating good interrater agreement.

2.8. Data Synthesis. The retained policy documents were heterogeneous and qualitative in nature with diverse designs, aims, and purposes. This diversity prompted the application of Noblit and Hare's metaethnographic approach complemented by a descriptive narrative of the findings [97]. This approach was appropriate because of its ability to generate a higher level of analysis while reducing the potential for research duplication [98]. The 
TABLE 3: Included policy category, focus, and target in Eswatini and Lesotho.

\begin{tabular}{|c|c|c|c|}
\hline Author, year, and reference & Document category & Thematic area & Target group \\
\hline $\begin{array}{l}\text { Ministry of Economic Planning and } \\
\text { Development, } 2019 \text { [62] }\end{array}$ & $\begin{array}{l}\text { Nonstatutory (soft) } \\
\text { policy }\end{array}$ & Economic growth and development & General public \\
\hline Government of Swaziland, 2013 [63] & $\begin{array}{l}\text { Nonstatutory (soft) } \\
\text { policy }\end{array}$ & Economic growth and development & General public \\
\hline $\begin{array}{l}\text { National Disaster Management Agency } \\
\text { and UNDP, } 2011 \text { [52] }\end{array}$ & $\begin{array}{l}\text { Nonstatutory (soft) } \\
\text { policy }\end{array}$ & Disaster risk reduction & General public \\
\hline $\begin{array}{l}\text { National Disaster Management Agency, } \\
2015 \text { [64] }\end{array}$ & $\begin{array}{l}\text { Nonstatutory (soft) } \\
\text { policy }\end{array}$ & Drought risk mitigation and adaptation & General public \\
\hline $\begin{array}{l}\text { FAO and Ministry of Agriculture and Co- } \\
\text { operatives (MOAC), } 2005 \text { [65] }\end{array}$ & $\begin{array}{l}\text { Nonstatutory (soft) } \\
\text { policy }\end{array}$ & Agriculture, food availability, and access & General public \\
\hline $\begin{array}{l}\text { Ministry of Tourism and Environmental } \\
\text { Affairs, } 2016 \text { [66] }\end{array}$ & $\begin{array}{l}\text { Nonstatutory (soft) } \\
\text { policy }\end{array}$ & $\begin{array}{c}\text { Climate change adaptation and } \\
\text { mitigation }\end{array}$ & General public \\
\hline MOAC, $2005[67]$ & $\begin{array}{l}\text { Nonstatutory (soft) } \\
\text { policy }\end{array}$ & $\begin{array}{c}\text { Food security, food access, and diet } \\
\text { diversification }\end{array}$ & General public \\
\hline $\begin{array}{l}\text { Ministry for Public Works and Transport, } \\
2002[68]\end{array}$ & $\begin{array}{l}\text { Nonstatutory (soft) } \\
\text { policy }\end{array}$ & $\begin{array}{c}\text { Climate change adaptation and } \\
\text { mitigation }\end{array}$ & $\begin{array}{c}\text { International community and } \\
\text { affected communities }\end{array}$ \\
\hline $\begin{array}{l}\text { Ministry of Tourism and Environmental } \\
\text { Affairs, } 2012 \text { [69] }\end{array}$ & $\begin{array}{l}\text { Nonstatutory (soft) } \\
\text { policy }\end{array}$ & $\begin{array}{c}\text { Climate change adaptation and } \\
\text { mitigation }\end{array}$ & $\begin{array}{l}\text { International community and } \\
\text { affected communities }\end{array}$ \\
\hline $\begin{array}{l}\text { National Disaster Management Agency } \\
\text { and UNDP, } 2008 \text { [70] }\end{array}$ & $\begin{array}{l}\text { Nonstatutory (soft) } \\
\text { policy }\end{array}$ & Disaster risk reduction & $\begin{array}{c}\text { International community and } \\
\text { affected communities }\end{array}$ \\
\hline $\begin{array}{l}\text { Ministry of Tourism and Environmental } \\
\text { Affairs, } 2016 \text { [71] }\end{array}$ & $\begin{array}{l}\text { Nonstatutory (soft) } \\
\text { policy }\end{array}$ & $\begin{array}{c}\text { Climate change adaptation and } \\
\text { mitigation }\end{array}$ & International community \\
\hline $\begin{array}{l}\text { Swaziland Environment Authority (SEA), } \\
1997 \text { [72] }\end{array}$ & $\begin{array}{l}\text { Nonstatutory (soft) } \\
\text { policy }\end{array}$ & Environmental protection & Government public \\
\hline $\begin{array}{l}\text { Ministry of Economic Planning and } \\
\text { Development, } 2007 \text { [73] }\end{array}$ & $\begin{array}{l}\text { Nonstatutory (soft) } \\
\text { policy }\end{array}$ & ty and vulnerability & General public \\
\hline $\begin{array}{l}\text { National Meteorological Service, } 2015 \\
{[74]}\end{array}$ & $\begin{array}{l}\text { Nonstatutory (soft) } \\
\text { policy }\end{array}$ & $\begin{array}{c}\text { Climate change adaptation and } \\
\text { mitigation }\end{array}$ & International community \\
\hline $\begin{array}{l}\text { National Disaster Management Agency, } \\
2015 \text { [75] }\end{array}$ & $\begin{array}{l}\text { Nonstatutory (soft) } \\
\text { policy }\end{array}$ & Disaster risk reduction & International community \\
\hline $\begin{array}{l}\text { National Disaster Management Agency, } \\
2015 \text { [76] }\end{array}$ & $\begin{array}{l}\text { Nonstatutory (soft) } \\
\text { policy }\end{array}$ & Emergency drought relief & Drought-affected communities \\
\hline Kingdom of Swaziland, 2006 [77] & $\begin{array}{l}\text { Statutory (hard) } \\
\text { policy }\end{array}$ & Disaster governance & General public \\
\hline Government of Lesotho, 2008 [78] & $\begin{array}{l}\text { Statutory (hard) } \\
\text { policy }\end{array}$ & Environmental protection & General public \\
\hline Government of Lesotho, 1997 [79] & $\begin{array}{l}\text { Statutory (hard) } \\
\text { policy }\end{array}$ & Disaster governance. & General public \\
\hline $\begin{array}{l}\text { Lesotho Meteorological Services, } 2017 \\
\text { [53] }\end{array}$ & $\begin{array}{l}\text { Nonstatutory (soft) } \\
\text { policy }\end{array}$ & $\begin{array}{c}\text { Climate change adaptation and } \\
\text { mitigation }\end{array}$ & General public \\
\hline $\begin{array}{l}\text { Ministry of Development Planning, } 2012 \\
{[80]}\end{array}$ & $\begin{array}{l}\text { Nonstatutory (soft) } \\
\text { policy }\end{array}$ & Economic growth and development & General public \\
\hline $\begin{array}{l}\text { Disaster Management Authority, } 2015 \\
\text { [81] }\end{array}$ & $\begin{array}{l}\text { Nonstatutory (soft) } \\
\text { policy }\end{array}$ & Emergency drought relief & Drought-affected communities \\
\hline $\begin{array}{l}\text { Ministry of Forestry Range and Soil } \\
\text { Conservation, } 2015 \text { [82] }\end{array}$ & $\begin{array}{l}\text { Nonstatutory (soft) } \\
\text { policy }\end{array}$ & $\begin{array}{l}\text { Drought and desertification mitigation } \\
\text { and environmental protection }\end{array}$ & General public \\
\hline $\begin{array}{l}\text { Lesotho Meteorological Services, } 2000 \\
\text { [83] }\end{array}$ & $\begin{array}{l}\text { Nonstatutory (soft) } \\
\text { policy }\end{array}$ & $\begin{array}{c}\text { Climate change adaptation and } \\
\text { mitigation }\end{array}$ & $\begin{array}{l}\text { International community and } \\
\text { affected communities }\end{array}$ \\
\hline $\begin{array}{l}\text { Lesotho Meteorological Services, } 2013 \\
\text { [84] }\end{array}$ & $\begin{array}{l}\text { Nonstatutory (soft) } \\
\text { policy }\end{array}$ & $\begin{array}{c}\text { Climate change adaptation and } \\
\text { mitigation }\end{array}$ & $\begin{array}{l}\text { International community and } \\
\text { affected communities }\end{array}$ \\
\hline $\begin{array}{l}\text { Lesotho Meteorological Services, } 2007 \\
\text { [85] }\end{array}$ & $\begin{array}{l}\text { Nonstatutory (soft) } \\
\text { policy }\end{array}$ & $\begin{array}{c}\text { Climate change adaptation and } \\
\text { mitigation }\end{array}$ & ublic \\
\hline $\begin{array}{l}\text { Lesotho Meteorological Services, } 2017 \\
\text { [86] }\end{array}$ & $\begin{array}{l}\text { Nonstatutory (soft) } \\
\text { policy }\end{array}$ & $\begin{array}{c}\text { Climate change adaptation and } \\
\text { mitigation }\end{array}$ & $\begin{array}{c}\text { International community and } \\
\text { general public }\end{array}$ \\
\hline $\begin{array}{l}\text { Disaster Management Authority, } 2015 \\
\text { [87] }\end{array}$ & $\begin{array}{l}\text { Nonstatutory (soft) } \\
\text { policy }\end{array}$ & Disaster risk reduction & International community \\
\hline $\begin{array}{l}\text { Ministry of Energy and Meteorology, } \\
2018 \text { [88] }\end{array}$ & $\begin{array}{l}\text { Nonstatutory (soft) } \\
\text { policy }\end{array}$ & $\begin{array}{c}\text { Climate change adaptation and } \\
\text { mitigation }\end{array}$ & General public \\
\hline UNOCHA, 2016 [89] & $\begin{array}{l}\text { Nonstatutory (soft) } \\
\text { policy }\end{array}$ & Emergency drought relief appeal & International community \\
\hline
\end{tabular}


TABle 3: Continued.

\begin{tabular}{|c|c|c|c|}
\hline Author, year, and reference & Document category & Thematic area & Target group \\
\hline $\begin{array}{l}\text { Southern African Development } \\
\text { Community, } 2010 \text { [90] }\end{array}$ & $\begin{array}{l}\text { Nonstatutory (soft) } \\
\text { policy }\end{array}$ & $\begin{array}{c}\text { Climate change adaptation and } \\
\text { mitigation }\end{array}$ & General public \\
\hline $\begin{array}{l}\text { Southern African Development } \\
\text { Community, } 2016 \text { [24] }\end{array}$ & $\begin{array}{l}\text { Nonstatutory (soft) } \\
\text { policy }\end{array}$ & Emergency drought relief appeal & International community \\
\hline
\end{tabular}

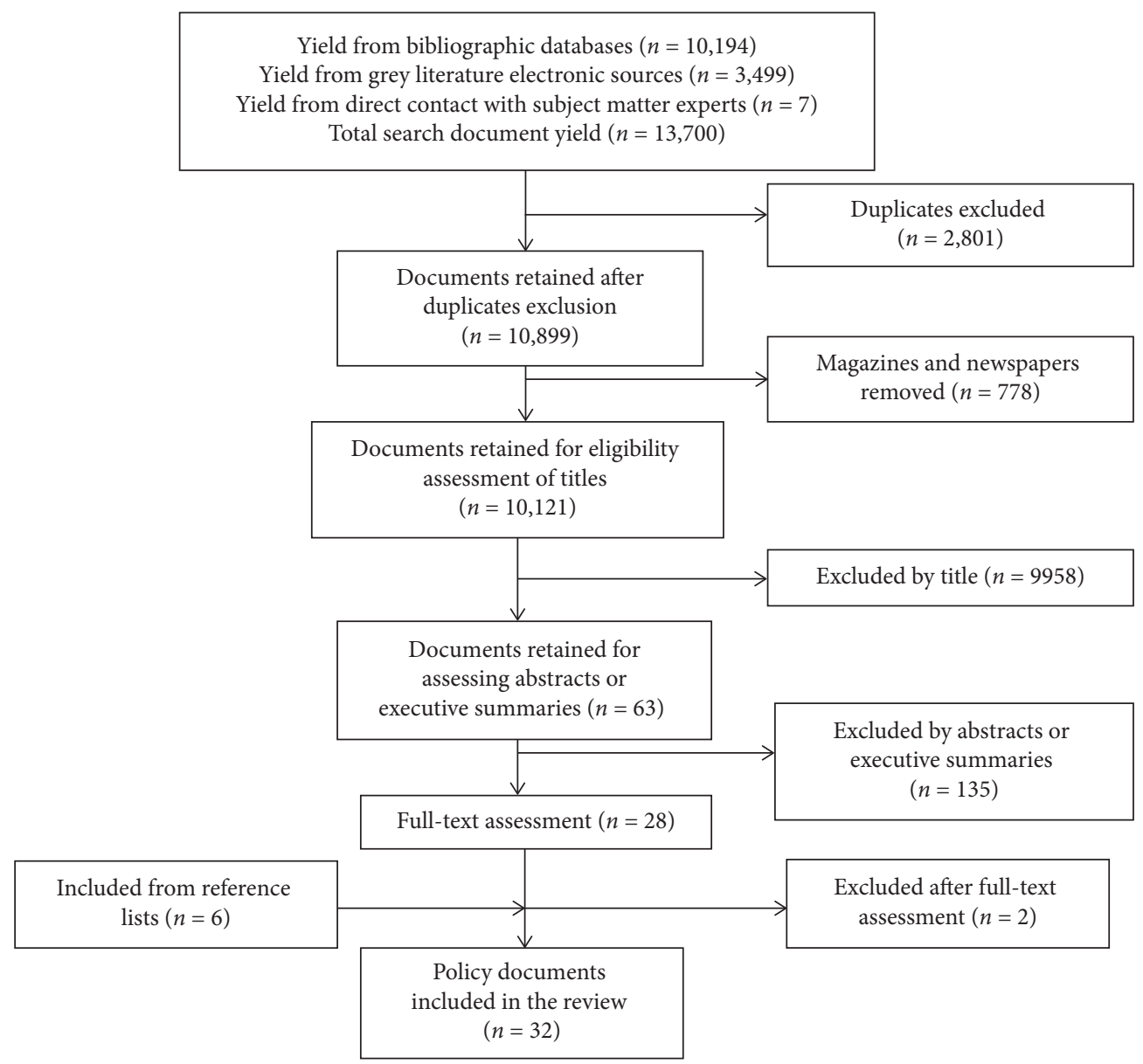

Figure 1: Policy document selection flowchart.

metaethnographic approach undertaken involved the following steps: firstly, we read and reread the policy documents to gain a good grasp of their content and concepts, identifying metaphors and/or themes and extracting the relevant data verbatim. Secondly, we used thematic analysis to synthesise each policy document's main concepts in order to develop categories (see Figure 2) from the main concepts and themes (first-order constructs) identified.

The categories denote related themes and concepts and initially included environmental, socioeconomic, and governance factors. These categories were reviewed and discussed to establish their relationships, and a similar process was undertaken for second-order constructs.

Thirdly, we translated the policy documents to each other by comparing the extracted concepts and metaphors of one policy document to those of another. However, this was a long and tedious process given the number $(n=32)$ of policy documents included. Thus, we chose one policy document from Eswatini which was ranked high on the quality assessment scale and compared its extracted themes and concepts with those of another highly ranked policy document from Lesotho. Thereafter, the outcome of the two documents' synthesis was used as the index to compare and contrast with each of the remaining policy documents, as prescribed by Noblit and Hare [97]. Indexing has been applied in other systematic reviews and metaethnographies and is credited with producing strong synthesis outcomes $[99,100]$. The third stage was followed by a higher order of interpretation to filter translations into lines of argument regarding whether the policies and regulatory frameworks promoted disaster resilience and how this was integrated within the policies. The first author (JKK) undertook the data synthesis steps in consultation with the other authors (BWS, KEA, and AMNR). 


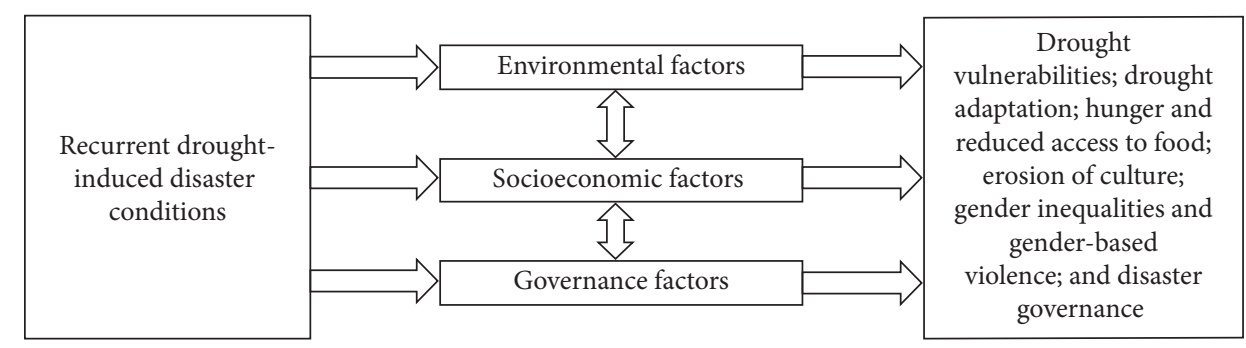

FIGURE 2: Reciprocal translation of studies into metathemes.

\section{Results}

This review is reported in accordance with the standard Preferred Reporting Items for Systematic Reviews and MetaAnalyses (PRISMA) guidelines [101]. The PRISMA checklist is appended (S1). The results of this study are presented in accordance with the characteristics, thematic outcomes, quality, and comprehensiveness of the reviewed policy documents.

3.1. Characteristics of Policy Documents. The search yielded 13,700 documents; of which 32 met our inclusion criteria (see Figure 1). All the retained documents fit our definition of policy. Among the retained policy documents, three $(n=3)$ were legislated hard policies; of these, one was from Eswatini and two were from Lesotho [77-79]. The rest were nonstatutory soft policies. Furthermore, seven $(n=7)$ policy documents had exceeded their intended lifespan by the time of the review $[24,63,70,75,76,80,89]$; one $(n=1)$ policy document was in the early implementation stage of $<2$ years ([62]; eleven $(n=11)$ policy documents were in the midimplementation stage between 3 and 5 years since coming into effect $[52,53,64,66,71,74,81,82,86-88]$; three $(n=3)$ policy documents had come into effect between 6 and 9 years prior to the review $[69,84,90]$; and ten $(n=10)$ policy documents were in the late implementation stage of $>10$ years $[65,67,68,72,73,77-79,83,85]$.

3.2. Thematic Outcomes. The reviewed policy documents' main thematic areas were agriculture and food security $(n=2)$, environment $(n=3)$, poverty reduction and economic development $(n=4)$, climate change mitigation $n=12)$, and drought and disaster governance $(n=11)$. Resilience was integrated therein and presented as a secondary theme. However, we noted the availability of two government disaster resilience strategies that were excluded from the review because they were not officially endorsed and were not publicly available. We present the key findings according to six metathemes that emerged based on the synthesis of the included policies (Figure 2).

3.2.1. Policy Responses to Address Vulnerability to ClimateInduced Recurring Drought. Four key areas of policy response addressed the underlying high vulnerability to recurrent drought. These key responses were as follows: addressing poverty and income distribution inequality; reducing reliance on rain-fed agriculture; strengthening macroeconomic performance; and promoting sustainable exploitation of natural resources [53, 67, 73, 89]. Firstly, poverty and inequality were key concerns and policy documents suggested that both countries' economies were skewed with high levels of inequalities, especially among the vast rural farming households with limited access to resources to adapt to recurrent drought hazards [24, 89]. Poverty was not limited to lack of a consistent income but extended to poor access to health care and education attainment that impeded resilience and wellbeing. Furthermore, poverty was linked to inability to secure adequate food, a critical determinant of a household and/or community's poverty status [73]. Government actions to address poverty were accelerating socioeconomic development; stimulating microeconomic opportunities in rural areas; increasing commercial farming partnership opportunities with surrounding communities; and promoting job opportunities for youth.

Secondly, dependence on rain-fed agriculture makes farming susceptible to recurrent drought and climate variability, leading to contraction of agricultural production, and impoverished rural subsistence farmers, and turning the two countries into net food importers. The policy responses were investment in irrigation systems; increased accessibility and affordability of smallholder irrigation schemes; partnerships with research institutions to mitigate vulnerability to crop failure; and stimulating synergies with the private sector, nongovernmental organisations (NGOs) and community groups to reduce household-level vulnerability.

Notwithstanding dependence on rain-fed agriculture, widespread land degradation had resulted in deforestation, degraded aquatic and soil systems, and altered ecosystems and had negatively affected livelihoods, human health, and wellbeing $[53,65,66,70,72,78,85]$. In addition, land degradation has been linked to recurrent droughts, which were identified as the main drivers of vulnerability $[53,66,72]$. Policy responses in Eswatini focused on integration of environmental management and economic development planning; sharing the responsibility for managing natural resources with communities; and developing partnerships on an equitable basis as well as sustainable use of rangelands $[65,66,73]$. Policy responses in Lesotho focused on promotion of climate-smart land and soil management improvement and maintaining the productivity of rangeland resources; promotion of sustainable management of forests; and enhancement of forest carbon stocks [53, 82, 85, 88]. 
3.2.2. Policy Responses to Increase Drought Adaptation. Of the 32 policy documents reviewed, nine $(n=9)$ outlined measures on rangeland management, early-warning enhancement, knowledgeability and communication, and social protection, as well as promoting research and innovation as responses to increase drought resilience and adaptation $[64-67,74,83,85,86,90]$. These responses cut across community, subnational, and national levels, where they were applied as collective measures. For instance, shared destocking of livestock was identified as a policy response to increase sustainable management of rangelands. Rangelands are communal properties in Eswatini and Lesotho used for communal grazing. However, their productivity is compromised by the inability to create a balance between livestock populations and the existing rangeland resources. Recurrent drought further exacerbates dwindling rangeland resources such as pasture and water. In addition, policy documents emphasised the need for community-centred early-warning and information-management systems for monitoring hazards and trends in variability and for enhancing the timely functionality of early-warning systems and the corresponding coordination of preparedness.

Furthermore, knowledgeability and communication were highlighted as important responses underscoring risk awareness, requiring mainstreaming and strengthening so as to promote adaptation in communities. However, there was acknowledgment of the lack of integration of indigenous knowledge and practices in government interventions. Thus, the call was made for integrating indigenous knowledge and practices into drought and climate change adaptation and aligning scientific, cultural, and indigenous knowledge on climate-induced hazards.

Social protection for the most vulnerable was another response of enabling the most vulnerable community members to withstand drought occurrence. The most vulnerable community members were considered those who are chronically poor and so unable to create and sustain economic activities or accumulate resources to cope with and recover from shock. Notwithstanding social protection, research was considered a vital action to enhance in-depth understanding of the causes, manifestations, and impacts of climate-induced drought, as well as mechanisms to respond to it. The policies called for research focusing on the development of cost-effective measures to mitigate and adapt to recurring drought, as well as the development and transfer of appropriate technology.

3.2.3. Policy Responses to Hunger and Reduced Access to Food. The majority of the policy documents $(n=29 / 32)$ highlighted agriculture and food security as highly vulnerable to the effects of recurring drought and climate change. Agricultural activities in both countries depend on rainfall which has become variable and unpredictable. Policy documents outlined that agriculture employs over $70 \%$ of the populations of Eswatini and Lesotho, who practise subsistence farming $[62,67,73,80,85]$. Recurring and prolonged drought occurrences negatively affect the subsistence agriculture which most of the population depends on. This results in food insecurity, hunger, and limited access to food especially among the rural subsistence farming communities. Actions to address hunger and reduced access to food were as follows: provision of food aid to the most vulnerable community members; advocating for local purchases of food aid by donors to stimulate private sector investment in agricultural production; reducing dependence on rain-fed agriculture through the practice of climate-smart agriculture and food-security systems; encouraging and promoting drought-tolerant crop varieties including indigenous crops; strengthening drought early-warning capabilities to provide timely advice to farmers; promoting agroforestry and intercropping to improve productivity; encouraging agroecological zoning matched with appropriate cropping, along with periodically reviewing and revising the zoning commensurate with the changing climatic context; legislating and enforcing monitoring of government-sanctioned food exports; and encouraging traditional rain-making rituals and other local practices $[52,53,65,67,73]$. While responses were similar in Eswatini and Lesotho, the ritualistic concept of rain-making was only highlighted in Eswatini [52].

\subsubsection{Policy Responses to Strengthen Sociocultural Resilience.} The erosion of cultural heritage was a defining difference between the policies of Eswatini and Lesotho. None of the reviewed policies $(n=0)$ in Eswatini addressed sociocultural resilience compared to five $(n=5)$ policy documents from Lesotho [53, 79, 83-85]. One of the reviewed documents $(n=1)$ addressing sociocultural resilience was from the SADC, a regional body encompassing all southern African countries including Eswatini and Lesotho [90]. The review revealed culture and traditions in Lesotho are intrinsically embedded in adaptation due to the continuous interaction of structures and human action. For example, natural resources such as rangelands sustain traditional livelihoods that depend on them. Our findings suggest that the construct of erosion of cultural heritage in recurrent drought-affected communities reflects the collective inability to withstand the changes driven by recurrent drought and climate change, which continuously weaken traditional safety nets and adaptation. As such, large rural populations, especially the youth, migrate to urban areas where they become detached from their traditions and cultural institutions [83]. Five responses to address the erosion of cultural heritage and strengthen sociocultural resilience were as follows: integrating climate change into cultural heritage and policy frameworks for sustainable development; sharing knowledge on emerging research outcomes and training communities to implement the research outcomes; preserving and documenting indigenous knowledge and practices; aligning scientific, cultural, and indigenous knowledge; and promoting biodiversity conservation. Other policy measures targeted public awareness and incentivising young people to remain in rural areas.

3.2.5. Policy Responses to Limit Gender Inequality and Gender-Based Violence. Nine policy documents $(n=9)$ suggested that the stress caused by dwindling resources due 
to recurrent drought aggravates gender inequality and gender-based violence, particularly sexual violence, in affected communities [52, 53, 65, 73, 75, 76, 80, 89, 90]. In addition, women and girls are culturally excluded from control of productive resources and entitlements, which undermines their ability to cope with disaster impacts. The proposed responses to address gender-based violence and inequalities were as follows: providing gender-sensitive guidelines and inclusive participation; accelerating socioeconomic development to redistribute wealth; promoting education attainment for women; training men and women on sexual and reproductive health; empowering women through policies that encourage female participation in political leadership and training; strengthening the capacity of the police, judiciary, and social welfare to promptly and adequately respond to gender-based violence; engaging men and women on sexual reproductive health, marriage, and inheritance laws; reviewing and repealing laws and customs that confine women to minority status; and promoting universal primary education for all children $[53,65,73,80,90]$.

\subsubsection{Policy Responses to Improve Disaster Governance.}

The reviewed policies highlighted three common disasterresilience governance mechanisms: international cooperation, internationalisation of responsibility, and internationalisation of relief response. International cooperation was represented in sixteen $(n=16)$ policy documents under a wide range of conditions [52, 53, 66, 68-71, 74, 75, $80,82-84,86,88,89]$. For example, the preparation and implementation of policies were contingent upon access to technical support, technology transfer, and development, as well as financial support received through international cooperation. Actions to increase international cooperation were as follows: bilaterally engaging with foreign governments and donors; participating in and committing to international conventions; and capturing and selling carbon emission reduction credits in global markets to reduce the negative effects of the changing climate $[52,53,73,80,84]$.

Five $(n=5)$ reviewed policy documents underscored the limited internal capacity to fund policy processes, which in a way transferred responsibility from the government to fund policies and placed this responsibility on the international community. This gave foreign funding agencies the leeway to drive policy processes that resonated with their strategic interests. In some instances, policy processes were externally driven by development partners and donor-dependent funding [24, 64, 74, 85, 86]. Responses for externalising responsibility were as follows: holding humanitarian appeals; improving the absorptive capacity of donor funding, aid management, and reporting and transparency; and enlisting the support of NGOs to raise resources to meet community needs.

Ten $(n=10)$ reviewed policy documents identified disaster relief as a common action of supporting communities to cope with and survive drought-induced disasters $[24,52,64,70,75,76,79,81,87,89]$. The main responses used in disaster relief were preparedness and vulnerability assessment, which involved identifying communities most at risk and appealing for aid, followed by providing emergency assistance like food and water to affected communities. Disaster relief is anchored in the disaster management laws of both countries, which gave a mandate to create national disaster management authorities [77, 79]. These authorities coordinate and monitor all relief response actions to support communities to prepare for, cope with, and survive hazard occurrences. Nonetheless, our findings suggest that disaster policy coordination was fragmented and decentralised in different units such as meteorological centres, environmental protection agencies, and many other government entities all contributing to similar objectives.

\subsection{Quality and Comprehensiveness of Policy Documents.} The findings suggest that eleven $(n=11 / 32)$ policy documents were of high quality, meaning they were robustly developed, eight $(n=8 / 32)$ were categorised as moderately developed, and thirteen $(n=13 / 32)$ policy documents were categorised as insufficiently developed. Notwithstanding the overall quality, most of the policy documents faltered in the monitoring and evaluation domain compared to the other domains of the assessment criteria. We noted that most policy documents did not have comprehensive evaluative frameworks addressing all five $(n=5)$ items in the domain of monitoring and evaluation (see Table 4 ). For example, only three $(n=3 / 32)$ policy documents indicated they had independent evaluation mechanisms $[53,85,89]$. One $(n=1)$ policy document had a quasi-independent evaluation mechanism which was assessed as moderately meeting the criteria [52]. Another $(n=1)$ policy document referred to an evaluation criterion but did not explicitly state it and was also assessed as moderately meeting the criteria [53]; ten $(n=10 / 32)$ policy documents had clear evaluation criteria $[24,52,62,69,70,72,73,76,86,88]$. However, we found only thirteen policy documents $(n=13 / 32)$ that had outcome measures for their implicit and explicit objectives $[52,53,63,65,68,70,72,73,78,80,85,88,89]$.

Similarly, only ten $(n=10 / 32)$ policy documents were properly costed, while nineteen $(n=19 / 32)$ documents indicated there was sufficient implementation capacity to achieve the policy objectives. The rest pointed to insufficient in-house capacity to achieve the policy objectives and called for external support to develop and build this capacity for policy effectiveness.

\section{Discussion}

Both Eswatini and Lesotho experience recurrent disasters, especially droughts, which affect large populations. The countries have different disaster-related policies focusing on areas such as disaster management, environmental protection and climate change, and poverty alleviation. However, none of the reviewed policies was specifically dedicated to disaster resilience. For example, none of the policies used the term "resilience" in their titles and some did not apply or refer to the term throughout their texts. The application of the term "resilience" in a policy title may not be sufficient to 
TABLE 4: Summary of quality assessment of policy documents based on logic of events framework.

\begin{tabular}{|c|c|c|c|c|}
\hline Dimension & Criteria & $\begin{array}{l}\text { No. of studies } \\
\text { that met } \\
\text { criteria }\end{array}$ & $\begin{array}{l}\text { No. of studies that } \\
\text { moderately or partially } \\
\text { met criteria }\end{array}$ & $\begin{array}{l}\text { No. of studies } \\
\text { that did not meet } \\
\text { criteria }\end{array}$ \\
\hline 1.0 Accessibility & $\begin{array}{c}\text { 1.1 The policy document is accessible online or in } \\
\text { hard copy }\end{array}$ & 32 & 0 & 0 \\
\hline \multirow{4}{*}{$\begin{array}{l}2.0 \text { Policy } \\
\text { background }\end{array}$} & $\begin{array}{l}\text { 2.1 There are established scientific grounds for the } \\
\text { policy }\end{array}$ & 31 & 0 & 1 \\
\hline & $\begin{array}{l}\text { 2.2 The goals are drawn from a conclusive review of } \\
\text { literature }\end{array}$ & 24 & 0 & 7 \\
\hline & $\begin{array}{l}2.3 \text { The policy source (e.g., authority and qual. or } \\
\text { quant. analysis or deduction) is established }\end{array}$ & 31 & 0 & 1 \\
\hline & 2.4 The policy provides alternatives & 26 & 0 & 6 \\
\hline \multirow{6}{*}{3.0 Goals } & $\begin{array}{l}\text { 3.1 The policy goals and/or objectives are clearly } \\
\text { stated }\end{array}$ & 23 & 0 & 9 \\
\hline & $\begin{array}{l}\text { 3.2 The policy goals and/or objectives are concrete } \\
\text { enough to be evaluated }\end{array}$ & 24 & 0 & 8 \\
\hline & $\begin{array}{l}\text { 3.3 The goals and/or objectives are clear in intent and } \\
\text { mechanism to achieve desired results without } \\
\text { prescribing what the change must be }\end{array}$ & 24 & 0 & 8 \\
\hline & $\begin{array}{l}3.4 \text { The action centres around improving the } \\
\text { population's wellbeing }\end{array}$ & 32 & 0 & 0 \\
\hline & $\begin{array}{l}\text { 3.5 The policy is supported by observations that align } \\
\text { with the policy proposal (external consistency) }\end{array}$ & 32 & 0 & 0 \\
\hline & $\begin{array}{l}\text { 3.6 The policy inferences are logically drawn from } \\
\text { available information (internal consistency) }\end{array}$ & 32 & 0 & 0 \\
\hline \multirow{3}{*}{ 4.0 Resources } & $\begin{array}{l}\text { 4.1 There are sufficient human resources allocated to } \\
\text { policy implementation }\end{array}$ & 24 & 0 & 8 \\
\hline & 4.2 The policy is well costed and budgeted for & 10 & 4 & 18 \\
\hline & $\begin{array}{c}\text { 4.3 The organisation has the necessary capacity to } \\
\text { implement the policy }\end{array}$ & 19 & 0 & 13 \\
\hline \multirow{7}{*}{$\begin{array}{l}\text { 5.0 Monitoring } \\
\text { and evaluation }\end{array}$} & $\begin{array}{c}\text { 5.1 The policy articulates a monitoring and evaluation } \\
\text { mechanism }\end{array}$ & 23 & 0 & 9 \\
\hline & 5.2 The policy has an independent body to evaluate it & 3 & 1 & 28 \\
\hline & $\begin{array}{l}5.3 \text { Outcome measures for each implicit and explicit } \\
\text { objective are established }\end{array}$ & 13 & 0 & 19 \\
\hline & $\begin{array}{l}\text { 5.4 Evaluation data are collected before, during, and } \\
\text { after the introduction of the policy }\end{array}$ & 9 & 5 & 18 \\
\hline & $\begin{array}{l}\text { 5.5 Follow-up takes place after a sufficient period to } \\
\text { allow policy effects to become evident }\end{array}$ & 15 & 1 & 16 \\
\hline & 5.6 Policy confounding factors are identified & 24 & 0 & 8 \\
\hline & 5.7 There are clear criteria for evaluation & 10 & 1 & 21 \\
\hline \multirow{2}{*}{$\begin{array}{l}6.0 \text { Public } \\
\text { opportunities }\end{array}$} & 6.1 There are multiple stakeholders involved & 23 & 0 & 7 \\
\hline & $\begin{array}{l}\text { 6.2 Stakeholders' concerns are recognised and } \\
\text { addressed to increase legitimacy }\end{array}$ & 17 & 0 & 15 \\
\hline \multirow{2}{*}{7.0 Obligations } & 7.1 Implementers' roles and obligations are specified & 22 & 0 & 10 \\
\hline & 7.2 Scientific results are compelling for action & 32 & 0 & 0 \\
\hline
\end{tabular}

demonstrate intentional inclusion of the concept, but it provides evidence of the intention. The majority of the policies passively interwove resilience as a thread across the various focus areas. This implies that disaster resilience in itself was not a main focus area of the policies. This finding is discouraging because both countries aim to transform and improve their societies' wellbeing and are committed to international conventions such as the United Nations SDGs, the Hyogo and Sendai frameworks for disaster-risk reduction, and the United Nations Convention to Combat Desertification (UNCCD) that seek to create resilient communities $[62,75,80,87,102]$. Despite these development aspirations and commitments to international conventions, our findings suggest that policies are insufficient to tackle disaster resilience, and hence, limited progress has been made. This finding is consistent with results showing both Eswatini and Lesotho have inadequately prepared for resilience and adaptation to the changing climate and recurring drought compared to neighbouring countries such as Botswana (Table 1). Botswana has a proactive drought policy that emphasises temporary employment linking relief and development for the rural poor; sewerage treatment and recycling pools across the country for irrigation; livestock fodder reserves and livestock 
advisory centres; as well as national conservation [103]. Other countries such as Australia, Brazil, and Moldova shifted their drought-management approaches from shortterm reactive interventions to long-term development approaches upon realisation that recurrent drought is unavoidable and remains one of the major threats to their economies [104-106]. Australia established a disaster resilience institute that emphasises strong linkages between knowledge management, research, policy, and operational excellence [104]. Similarly, Brazil invested in addressing structural deficits that aggravate vulnerability and collaborating with entities such as the World Bank, the national drought centres of the United States and Mexico, and other drought research organisations on information-sharing and framing evidence-based priorities for enhancement of drought resilience $[105,107]$. Moldova focused on a longterm strategy of integrated drought management with emphasis on developing scientific measures to reduce drought vulnerability and risk, as well as developing strong channels for dissemination of scientific knowledge and practices [106, 108].

We found many policy responses dedicated to food security and agriculture, which is the mainstay of the majority of the two countries' populations. Nonetheless, policies focused mainly on improving agricultural systems. In the context of recurring drought and subsistence farming, policies were short on transformative ideas for tackling poverty, inequality, and putting more cash into rural farmers' hands. The effects of recurring drought make it difficult for rural subsistence farmers to sustain agricultural productivity or produce or purchase food and subject them to undernutrition and the associated consequences. We argue that resolving issues of poverty and inequality is a normative ideal for resilience to recurrent drought and the subsequent transformative development [109].

This systematic review shows key policies were driven by the desire to honour international commitments and cooperation. This approach garnered support for the host countries' interventions in the form of technical and technological transfer, as well as financial support in areas of humanitarian assistance, drought, and climate change adaptation. However, it meant the host governments abdicated their responsibility to independently plan and allocate resources within their means. As such, the extent to which public policy objectives could be achieved was contingent on the availability of aid and the technical cooperation. This emerged as a key condition for Eswatini's and Lesotho's participation in international governance on climate change, environment, and disaster management such as the Hyogo Framework for Action to build the resilience of nations and communities, the UNCCD, and the UN Framework Convention on Climate Change $[69,82,87]$. The internationalisation of climate-induced disasters has perpetuated dependence on foreign assistance and limited inherent solutions in favour of donor-driven approaches. This finding is consistent with previous studies that point to the ineffectiveness of aid dependence in building community resilience to the problem of recurring drought [25, 28, 40]. Furthermore, relying on external support for national policy formulation and implementation presents a risk to state sovereignty and could undermine domestic interests such as the primary responsibility to meet the needs of affected communities in favour of foreign interests [110].

Our review has found evidence to suggest that gender inequality and gender-based violence are prevalent and aggravated during times of adversity, especially during drought periods. However, most of the policy responses were reactive and none of the responses proposed to educate young boys as allies in prevention of gender inequity. Evidence suggests that engaging young boys in helping to overturn gender inequity and unfair social norms is an effective and sustainable strategy for dealing with the problems [111]. Inequality and exposure to gender-based violence weaken household and community cohesion, as well as the ability to adapt to adverse conditions.

The reviewed policy documents were weak in the evaluation and monitoring domain, suggesting that the policy formulation process did not thoroughly consider the role and importance of policy monitoring and evaluation. For example, most of the policy documents lacked evaluation plans and those that attempted to address monitoring and evaluation provided insufficient levels of detail. This made it difficult to determine the policy measures from what was stated in the documents and whether empirical evidence had been used to inform policy formulation. This suggests a lack of understanding of the relevance of measures of effectiveness by policymakers. Regardless of how good a policy may appear on paper, its effectiveness can only be determined by robust monitoring and evaluation in completing the policy cycle to inform subsequent policy decisions $[96,112]$.

Disaster governance in both countries is rooted in disaster governance laws. These laws focus on reactive emergency responses and remain silent on building community resilience to recurrent drought. By failing to incorporate disaster and/or drought resilience, the laws are inadvertently negating the Sendai Framework for Disaster Risk Reduction, which calls for greater partnership between disaster management agencies and for interventions that strengthen communities' capacity to cope with and adapt to disasters. The Sendai Framework is an important post-2015 international disaster risk agreement that prioritises four key areas: understanding disaster risk in all its dimensions; strengthening disaster-risk governance capacity at various levels; enhancing disaster resilience; and strengthening preparedness capacities for disaster response [113]. These four areas promote and improve communities' abilities to absorb and adapt to emerging risks and transform themselves to living in their altered environment of recurring disaster or drought risk [114]. Both Eswatini and Lesotho are signatories to the Sendai Framework, but the two countries' laws predate the Framework and have not incorporated resilience as a main thematic area to align with it. Furthermore, the two countries' disaster management authorities specialise in disaster management and recovery operations, as reflected in the various national action plans for drought emergency response and recovery. 
The policy documents reviewed were silent on what happens after a drought crisis. This indicates an absence of concrete policy responses to gradually build and strengthen community resilience during the good times, although gradual interventions in noncrisis times are critical building blocks for community resilience [115]. As such, there was no indication of planned continuity of action postemergency periods, which implies limited or no attention or resource allocation to multilevel interventions that can enhance the capacity to live with drought. This is consistent with findings from other studies conducted in different regions $[115,116]$.

The reviewed policy documents were created and reside in different policy units and often disconnected from each other, although they sought to contribute to common objectives. For example, the climate change policy in Lesotho was created by the meteorological centre while the disaster management agency is hosted by the Prime Minister's office. In Eswatini, the Ministry of Tourism and Environmental Affairs coordinates climate change adaptation while the Prime Minister's office hosts the national disaster management agency. Creating overlapping policies in different departments is costly and inefficient. Evidence suggests that climate change remains the key driver of environmental hazards such as drought [117]. Therefore, these governments could strengthen the synergies between policies on climate change, drought adaptation, and disaster risk by consolidating them under a single climate and disaster resilience unit. This would not only improve coordination and efficiencies, but also leverage the shared capacities and knowledge.

\section{Limitations}

We acknowledge that our review may have missed a unique perspective from policy documents that were not publicly available or officially endorsed by their governments and so did not meet the inclusion criteria. Nonetheless, the review has explored a range of literature to overcome this limitation. The included policy documents were from Eswatini and Lesotho and from Southern African regional bodies such as the SADC. Therefore, applying the findings beyond the Southern African region should be handled with caution. The study scope was limited to national- and regional-level policies that were available and accessible. Subnational-level policies were excluded because they were inaccessible.

\section{Conclusion}

We systematically reviewed and assessed policy documents using approaches and tools that highlighted strengths, weaknesses, and gaps that can be prioritised in order to promote and strengthen drought resilience. Critical gaps identified were limited understanding of the role of policy monitoring and evaluation, poor policy costing, and inability to independently fund the policy-formulation process. Additionally, reliance on foreign support to stimulate and drive the policy process replaced local drought resilience needs with foreign-driven policy objectives different from local drought resilience needs and capacities.
There are commonalities in the two countries' policy responses to drought. Drought-resilience policy responses were secondary to other themes across the policy documents. Some policy documents had significant proportions of policy responses related to drought and disaster resilience, while others had very few such responses. Disappointingly, the construct of drought resilience was not strongly articulated as a major policy goal despite the high vulnerability and recurring nature of drought. This suggests poor understanding of the concept in both countries. There is an urgent need to promote better understanding of drought resilience in order to motivate policymakers to steer away from reactive interventions and position resilience as a major national policy goal in both countries. In addition, specific research on drought resilience is necessary to benchmark and evaluate policies against objectives and so inform subsequent policies.

We hope this systematic review will stimulate policy revisions and a paradigm shift towards long-term and sustainable approaches that harness and enhance rural populations' adaptation to recurrent drought. Ideally, the governments of Eswatini and Lesotho should consider reviewing their laws, policies, and policy responses in order to emphasise a specific focus on drought resilience to expedite inclusive growth and safeguard their development gains and the health and wellbeing of the majority of their populations who are rural-based populations. Such policies have the potential to reduce the costly and reactive aiddependent interventions and government expenditure which is an important step towards self-sustenance and good governance. The success of the policy shift will provide a new narrative of hope emerging from countries known for poor health outcomes, poverty and hunger. More importantly, recurrent drought-induced hunger and the associated illhealth will be resolved. Furthermore, the successes will stimulate reexamination of drought policies across the region and beyond.

\section{Conflicts of Interest}

The authors declare that there are no conflicts of interest regarding the publication of this article.

\section{Acknowledgments}

The authors would like to thank Ms Kaysha Carroll of Western Sydney University for her support in the preparation of the search strategy.

\section{Supplementary Materials}

Table S1: the PRISMA checklist. Table S2: scoring of policy documents using the logic of events theoretical framework. (Supplementary Materials)

\section{References}

[1] A. Holloway, "Disaster risk in Africa: dynamic discourse or dysfunctional dialogue," in Risk and Africa: Multi-Disciplinary Empirical Approaches, L. Bloemertz, 
M. Doevenspeck, E. Macamo, and D. Muller-mahn, Eds., LIT Verlag Münster, Berlin, Germany, 2012.

[2] J. K. Kamara, K. Agho, and A. M. N. Renzaho, "Combating recurrent hazards: evidence from rural Lesotho and Eswatini-a qualitative study," Environmental Hazards, pp. 1-21, 2019.

[3] H. L. Berry, R. Baillie, and W. Gunthorpe, "Rural mental health impacts of climate change. Commissioned report for the garnaut climate change review," Australian National University, Canberra, Australia, 2018.

[4] H. L. Berry, K. Bowen, and T. Kjellstrom, "Climate change and mental health: a causal pathways framework," International Journal of Public Health, vol. 55, no. 2, pp. 123-132, 2010.

[5] M. Keshavarz, E. Karami, and F. Vanclay, "The social experience of drought in rural Iran," Land Use Policy, vol. 30, no. 1, pp. 120-129, 2013.

[6] J. Kamara, B. Akombi, K. Agho, and A. Renzaho, "Resilience to climate-induced disasters and its overall relationship to well-being in southern Africa: a mixed-methods systematic review," International Journal of Environmental Research and Public Health, vol. 15, no. 11, p. 2375, 2018.

[7] J. Belle and M. Hlalele, "Vulnerability assessment of agricultural drought hazard: a case of Koti-Se-Phola community council, Thabana Morena, Mafeteng district in Lesotho," Journal of Geography \& Natural Disasters, vol. 5, no. 2, 2015.

[8] C. Stanke, M. Kerac, C. Prudhomme, J. Medlock, and V. Murray, "Health effects of drought: a systematic review of the evidence," PLoS Currents, vol. 5, no. 5, 2013.

[9] National Drought Mitigtion Center, Drought Basics, National Drought Mitigtion Center, Lincoln, NE, USA, 2019.

[10] National Oceanic and Atmospheric Administration, What is Meant by the Term Drought?, National Oceanic and Atmospheric Administration, Silver Spring, MD, USA, 2004.

[11] J. Thurlow, T. Zhu, and X. Diao, "Current climate variability and future climate change: estimated growth and poverty impacts for Zambia," Review of Development Economics, vol. 16, no. 3, pp. 394-411, 2012.

[12] D. Conway, E. A. van Garderen, D. Deryng et al., "Climate and southern Africa's water-energy-food nexus," Nature Climate Change, vol. 5, no. 9, pp. 837-846, 2015.

[13] C. Brown, R. Meeks, K. Hunu, and W. Yu, "Hydroclimate risk to economic growth in sub-Saharan Africa," Climatic Change, vol. 106, no. 4, pp. 621-647, 2011.

[14] C. W. Rigby, A. Rosen, H. L. Berry, and C. R. Hart, "If the land's sick, we're sick:* the impact of prolonged drought on the social and emotional well-being of Aboriginal communities in rural New South Wales," Australian Journal of Rural Health, vol. 19, no. 5, pp. 249-254, 2011.

[15] J. O. Oviawe, "How to rediscover the ubuntu paradigm in education," International Review of Education, vol. 62, no. 1, pp. 1-10, 2016.

[16] E. Skoufias and K. Vinha, "Climate variability and child height in rural Mexico," Economics \& Human Biology, vol. 10, no. 1, pp. 54-73, 2012.

[17] J. M. Bauer and S. Mburu, "Effects of drought on child health in Marsabit district, Northern Kenya," Economics \& Human Biology, vol. 24, pp. 74-79, 2017.

[18] K. Grace, F. Davenport, C. Funk, and A. M. Lerner, "Child malnutrition and climate in Sub-Saharan Africa: an analysis of recent trends in Kenya," Applied Geography, vol. 35, no. 12, pp. 405-413, 2012.
[19] J. Hoddinott and B. Kinsey, "Child growth in the time of drought," Oxford Bulletin of Economics and Statistics, vol. 63, no. 4, pp. 409-436, 2001.

[20] S. Lazzaroni and N. Wagner, "Misfortunes never come singly: structural change, multiple shocks and child malnutrition in rural Senegal," Economics \& Human Biology, vol. 23, pp. 246-262, 2016.

[21] A. De Waal, A. Taffesse, and L. Carruth, "Child survival during the 2002-2003 drought in Ethiopia," Global Public Health, vol. 1, no. 2, pp. 125-132, 2006.

[22] E. Puentes, F. Wang, J. R. Behrman et al., "Early life height and weight production functions with endogenous energy and protein inputs," Economics \& Human Biology, vol. 22, pp. $65-81,2016$.

[23] M. Rieger and N. Wagner, "Child health, its dynamic interaction with nutrition and health memory-evidence from Senegal," Economics \& Human Biology, vol. 16, pp. 135-145, 2015.

[24] Southern African Development Community, Regional Humanitarian Appeal, Southern African Development Community, Gabarone, Botswana, 2016.

[25] A. Holloway, "Drought emergency, yes...drought disaster, no: Southern Africa 1991-1993," Cambridge Review of International Affairs, vol. 14, no. 1, pp. 254-276, 2000.

[26] L. E. Askew and M. Sherval, "Short-term emergency or recurring climatic extreme: a rural town perspective on drought policy and programs," Australian Journal of Public Administration, vol. 71, no. 3, pp. 290-302, 2012.

[27] M. Sherval and L. E. Askew, "Experiencing "drought and more": local responses from rural Victoria, Australia," Population and Environment, vol. 33, no. 4, pp. 347-364, 2012.

[28] A. Holloway, "Disaster risk reduction in southern Africa," African Security Review, vol. 12, no. 1, pp. 29-38, 2003.

[29] J. K. Kamara, N. Wali, K. Agho, and A. M. N. Renzaho, "Resilience to climate-induced disasters and its overall impact on well-being in Southern Africa: a mixed-methods systematic review protocol," Systematic Reviews, vol. 7, no. 1, p. 127, 2018.

[30] United Nations and SADCC, Drought Emergency in Southern Africa (DESA): Consolidated UN-SADCC Appeal: Angola, Botswana, Lesotho, Malawi, Mozambique, Namibia, Swaziland, Tanzania, Zambia, Zimbabwe, UNOCHA, Geneva, Switzerland, 1992.

[31] C. Vanderpost, “The 1991 census and Botswana's population problem," Botswana Notes and Records, vol. 24, pp. 39-48, 1992.

[32] Namibia Statistics Agency, Population and Housing Census Main Report, Namibia Statistics Agency, Windhoek, Namibia, 2011.

[33] Statistics South Africa, Community Survey: Statistical Release P0301, Statistics South Africa, Pretoria, South Africa, 2016.

[34] R. Torenvlied and A. Akkerman, "Theory of "soft" policy implementation in multilevel systems with an application to social partnership in The Netherlands," Acta Politica, vol. 39, no. 1, pp. 31-58, 2004.

[35] M. Foucault, "The subject and power," Critical Inquiry, vol. 8, no. 4, pp. 777-795, 1982.

[36] M. Foucault, Archaeology of Knowledge, Routledge, London, UK, 2nd edition, 2002.

[37] D. Harvey, Brief History of Neoliberalism, Oxford University Press, Oxford, UK, 2005.

[38] S. Ward, C. Bagley, J. Lumby, T. Hamilton, P. Woods, and A. Roberts, "What is "policy" and what is "policy response"? 
An illustrative study of the implementation of the Leadership Standards for Social Justice in Scotland," Educational Management Administration \& Leadership, vol. 44, no. 1, pp. 43-56, 2016.

[39] S. S. Green, Security Program and Policies: Principles and Practices, Pearson Education, Indianapolis, IN, USA, 2nd edition, 2014.

[40] J. K. Kamara, K. Agho, and A. M. N. Renzaho, "Understanding disaster resilience in communities affected by recurrent drought in Lesotho and Swaziland-A qualitative study," PLoS One, vol. 14, no. 3, Article ID e0212994, 2019.

[41] I. Masih, S. Maskey, F. E. F. Mussá, and P. Trambauer, "A review of droughts on the African continent: a geospatial and long-term perspective," Hydrology and Earth System Sciences, vol. 18, no. 9, pp. 3635-3649, 2014.

[42] J. Msangi, "Drought hazard and desertification management in the drylands of Southern Africa," Environmental Monitoring and Assessment, vol. 99, no. 1-3, pp. 75-87, 2004.

[43] D. Tschirley, "Anticipating and responding to drought emergencies in southern Africa: lessons from the 2002-2003 experience," in Food Security International Development Working Papers, Michigan State University, East Lansing, MI, USA, 2004.

[44] Food and Agricultural Organization, 2018/19 El Niño Response Plan for Southern Africa 2019, Food and Agricultural Organization of the United Nations, Johannesburg, South Africa, 2019.

[45] Southern Africa Development Community (SADC), "SADC Humanitarian Response Monitoring Report-December 2016," SADC Secretariat, Gaborone, Botswana, 2016.

[46] M. E. Moeletsi and S. Walker, "Agroclimatological suitability mapping for dryland maize production in Lesotho," Theoretical and Applied Climatology, vol. 114, no. 1-2, pp. 227236, 2013.

[47] J. Pound, J. Michiels, and R. Bofifacio, "Special report: FAO/ WFP crop and food security assessment mission to Swaziland," Food and Agriculture Organisation and World Food Programme, Rome, Italy, 2015.

[48] R. Everist, J. Murray, and J. Williams, South Africa, Lesotho and Swaziland, Lonely Planet, London, UK, 4th edition, 2000.

[49] N. M. Kamwangamalu, "Language in education policy and planning in Africa's monolingual Kingdoms of Lesotho and Swaziland," in Language Policies in Education:critical Issues, J. W. Tollefson, Ed., Routledge, New York, NY, USA, 2013.

[50] EPR Atlas, Ethnicity in Swaziland, 2017, https://growup.ethz. ch/atlas/pdf/Swaziland.pdf.

[51] EPR Atlas, Ethnicity in Lesotho, 2017, https://growup.ethz. ch/atlas/pdf/Lesotho.pdf.

[52] National Disaster Management Agency and United Nations Development Programme, National Disaster Risk Managment Policy, National Disaster Management Agency, Mbabane, Swaziland, 2011.

[53] Lesotho Meteorological Services, Lesotho's National Climate Change Policy, Ministry of Energy and Meteorology, Maseru, Lesotho, 2017.

[54] UN DESA, "Sustainable development goals report," UN DESA, New York, NY, USA, 2018.

[55] F. A. Miller and K. Alvarado, "Incorporating documents into qualitative nursing research," Journal of Nursing Scholarship, vol. 37, no. 4, pp. 348-353, 2005.

[56] Center for Disease Control and Office of the Associate Director for Policy, Definition of Policy, 2011 https://www.cdc. gov/policy/analysis/process/docs/policyDefinition.pdf.
[57] S. P. Rao, Bussiness Policy and Strategic Management: Text and Cases, Hilmalaya Publishing House, New Delhi, India, 2nd edition, 2016.

[58] D. D. Soekarjo, A. Roshita, A.-M. Thow, M. Li, and J. H. Rah, "Strengthening nutrition-specific policies for adolescents in Indonesia: a qualitative policy analysis," Food and Nutrition Bulletin, vol. 39, no. 3, pp. 475-486, 2018.

[59] C. Lachat, S. Otchere, D. Roberfroid et al., "Diet and physical activity for the prevention of noncommunicable diseases in low- and middle-income countries: a systematic policy review," PLoS Medicine, vol. 10, no. 6, Article ID e1001465, 2013.

[60] W. E. Walker, "Policy analysis: a systematic approach to supporting policymaking in the public sector," Journal of Multi-Criteria Decision Analysis, vol. 9, no. 1-3, pp. 11-27, 2000.

[61] H. Nudzor, "What is "policy," a problem solving-definition or a process conceptualization?," Educational Futures, vol. 2, no. 1, pp. 85-96, 2009.

[62] Ministry of Economic Planning and Development, Eswatini National Development Plan 2019/20-2021/22: Towards Economic Recovery, Ministry of Economic Planning and Development, Mbabane, Eswatini, 2019.

[63] Government of Swaziland, His Majesty's Government Programme of Action 2013-2018, Government of Swaziland, Mbabane, Swaziland, 2013.

[64] National Disaster Managment Agency, National Emergency Response, Mitigation and Adaptation Plan (NERMAP) January 2016 to March 2022, National Disaster Management Agency, Mbabane, Swaziland, 2015.

[65] Food and Agriculture Organization (FAO) and MOAC, Comprehensive Agricultural Sector Policy (CASP), MOAC, Mbabane, Swaziland, 2005.

[66] Ministry of Tourism and Environmental Affairs, Swaziland National Climate Change Policy, Ministry of Tourism and Environmental Affairs, Mbabane, Swaziland, 2016.

[67] Ministry of Agriculture and Co-Operatives (MOAC), $\mathrm{Na}$ tional Food Security Policy for Swaziland, MOAC, Mbabane, Swaziland, 2005.

[68] Ministry for Public Works and Transport, Swaziland's First National Communication to the UNFCCC: National Report on Climate Change, Ministry for Public Works and Transport, Mbabane, Swaziland, 2002.

[69] Ministry of Toursim and Environmental Affairs, Swaziland's Second National Communication to the United Nations Framework Convention on Climate Change, Ministry of Toursim and Environmental Affairs, Mbabane, Swaziland, 2012.

[70] National Disaster Management Agency and United Nations Development Programme, Swaziland Disaster Risk Reduction National Action Plan 2008-2015, National Disaster Management Agency and United Nations Development Programme, Mbabane, Swaziland, 2008.

[71] Ministry of Tourism and Environmental Affairs, Swaziland's Third National Communication to the United Nations Framework Convention on Climate Change, Ministry of Tourism and Environmental Affairs, Mbabane, Swaziland, 2016.

[72] Swaziland Environment Authority (SEA), Swaziland Environment Action Plan (SEAP), Ministry of Natural Resources, Environment and Energy, Mbabane, Swaziland, 1997.

[73] Ministry of Economic Planning and Development, Swaziland Poverty Reduction Strategy and Action Plan (PRSAP), Ministry of Economic Planning and Development, Mbabane, Swaziland, 2007. 
[74] National Meteorological Service, Swaziland's Intended Nationally Determined Contribution (INDC) to the Convention, National Meteorological Service, Mbabane, Swaziland, 2015.

[75] National Disaster Management Agency, National Progress Report on the Implementation of the Hyogo Framework for Action (2013-2015), National Disaster Management Agency, Mbabane, Swaziland, 2015.

[76] National Disaster Management Agency, Swaziland Comprehensive National Drought Response Plan, April 2016 to March 2017, National Disaster Management Agency, Mbabane, Swaziland, 2015.

[77] Kingdom of Swaziland, Disaster Managment Act No. 1 2006, Mbabane, Swaziland.

[78] Government of Lesotho, Environment Act No. 10 of 2008, Government of Lesotho, Maseru, Lesotho, 2008.

[79] Government of Lesotho, Disaster Management Act No. 2 of 1997, Government of Lesotho, Maseru, Lesotho, 1997.

[80] Ministry of Development Planning, Lesotho National Strategic Development Plan 2012/13-2016/17, Ministry of Development Planning, Maseru, Lesotho, 2012.

[81] Disaster Management Authority, National Drought Emergency Response Plan, Disaster Management Authority, Maseru, Lesotho, 2015.

[82] Ministry of Forestry Range and Soil Conservation, Lesotho National Action Programme in Natural Resource Management, Combating Desertification and Mitigating the Effects of Drought, Ministry of Forestry, Range and Soil Conservation, Maseru, Lesotho, 2015.

[83] Lesotho Meteorological Services, First National Communication to the Conference of the Parties to the United Nations Framework Convention on Climate Change: National Report on Climate Change, Ministry of Natural Resources, Maseru, Lesotho, 2000.

[84] Lesotho Meteorological Services, Lesotho's Second National Communication under the United Nations Framework Convention on Climate Change, Lesotho Meteorological Services, Maseru, Lesotho, 2013.

[85] Lesotho Meteorological Services, Lesotho National Adaptation Programme of Action (NAPA) on Climate Change, Lesotho Meteorological Services, Maseru, Lesotho, 2007.

[86] Lesotho Meteorological Services, Lesotho's Nationally Determined Contribution under the United Nations Framework Convention on Climate Change, Ministry of Energy and Meteorology, Maseru, Lesotho, 2017.

[87] Disaster Management Authority, Lesotho National Progress Report on the Implementation of the Hyogo Framework for Action (2013-2015), Disaster Management Authority, Maseru, Lesotho, 2015.

[88] Ministry of Energy and Meteorology, Lesotho National Climate Change Policy Implementation Strategy (NCCPIS), Ministry of Energy and Meteorology, Maseru, Lesotho, 2017.

[89] UNOCHA, RIASCO Action Plan for Southern Africa: Response Plan for the El Niño Induced Drought in Southern Africa May 2016-April 2017, UNOCHA, Johannesburg, South Africa, 2016.

[90] Southern African Development Community (SADC), Southern Africa Sub-Regional Framework of Climate Change Programmes: Adaptation and Mitigation Actions, Supported by Enabling Measures of Implementation, Southern African Development Community (SADC), Gaborone, Botswana, 2010.

[91] C. Lefebvre, "Searching for and selecting studies," in Cochrane Handbook for Systematic Reviews of Interventions,
J.P. T. Higgins and S. Green, Eds., John Wiley \& Sons, Chichester, UK, 2019.

[92] J. Tyndall and Flinders University, "AACODS checklist," 2010, https://dspace.flinders.edu.au/xmlui//bitstream/handle/2328/ 3326/AACODS_Checklist.pdf;jsessionid=AC42DFAFF5785 B12B2822D1320159067.

[93] C. Hurley, F. Shiely, J. Power et al., "Risk based monitoring (RBM) tools for clinical trials: a systematic review," Contemporary Clinical Trials, vol. 51, pp. 15-27, 2016.

[94] G. H. Von Wright, "Determinism and the study of man," in Essays on Explanation and Understanding, J. Manninen and R. Tuomela, Eds., Springer, Berlin, Germany, 1976.

[95] K. K. Cheung, M. Mirzaei, and S. Leeder, "Health policy analysis: a tool to evaluate in policy documents the alignment between policy statements and intended outcomes," Australian Health Review, vol. 34, no. 4, pp. 405413, 2010.

[96] A. Rütten, G. Lüschen, T. von Lengerke et al., "Determinants of health policy impact: comparative results of a European policymaker study," Sozial-und Präventivmedizin, vol. 48, no. 6, pp. 379-391, 2003.

[97] G. Noblit and R. Hare, "Meta-ethonography: synthethising qualitative studies," in Qualitative Research Methods, Vol. II, SAGE, Newburry Park, CA, USA, 1998.

[98] S. Atkins, S. Lewin, H. Smith et al., "Conducting a metaethnography of qualitative literature: lessons learnt," $B M C$ Medical Research Methodology, vol. 8, no. 1, p. 21, 2008.

[99] R. Campbell, P. Pound, C. Pope et al., "Evaluating metaethnography: a synthesis of qualitative research on lay experiences of diabetes and diabetes care," Social Science of Medicine, vol. 56, no. 4, pp. 671-684, 2003.

[100] F. Jamal, A. Fletcher, A. Harden, H. Wells, J. Thomas, and C. Bonell, "The school environment and student health: a systematic review and meta-ethnography of qualitative research," BMC Public Health, vol. 13, no. 1, p. 798, 2013.

[101] D. Moher, A. Liberati, J. Tetzlaff, and D. G. Altman, "Preferred reporting items for systematic reviews and metaanalyses: the PRISMA statement," International Journal of Surgery, vol. 8, no. 5, pp. 336-341, 2010.

[102] United Nations Convention to Combat Desertification in Those Countries Experiencing Serious Drought And/or Desertification, Particularly in Africa, 1994, United Nations: Bonn, Germany.

[103] M. Manthe-Tsuaneng, Drought Conditions and Management Strategies in Botswana, Ministry of Environment, Wildlife and Tourism, Gaborone, Botswana, 2014.

[104] Council of Australian Governments, National Strategy for Disaster Resilience: Building the Resilience of Our Nation to Disasters, Australian Institute for Disaster resilience, Canberra, Australia, 2011.

[105] E. Bretan and N. L. Engle, "Drought preparedness policies and climate change adaptation and resileince measures in Brazil: an institutional change," in Evaluating Climate Change Action for Sustainable Development, I. J. Uitto, J. Puri, and D. R. van den Berg, Eds., pp. 305-326, Springer Open, Cham, Switzerland, 2017.

[106] Government of Moldova, National Action Plan to Combat Desertification 2000, Governmnet of Moldova, Chisinau, Moldava, 2000.

[107] M. C. Lemos, Y.-J. Lo, D. R. Nelson, H. Eakin, and A. M. Bedran-Martins, "Linking development to climate adaptation: leveraging generic and specific capacities to reduce vulnerability to drought in NE Brazil," Global Environmental Change, vol. 39, pp. 170-179, 2016. 
[108] Global Water Partnership Central and Eastern Europe, Natural Small Water Retention Measures Combining Drought Mitigation, Flood Protection and Biodiversity Conservation: Guidelines, Global Water Partnership Central and Eastern Europe, Bratislava, Slovakia, 2015.

[109] G. Wilson, "Multifunctional "quality" and rural community resilience," Transactions of the Institute of British Geographers, vol. 35, no. 3, pp. 364-381, 2010.

[110] J. Golub, "Sovereignty and subsidiarity in EU environmental policy," Political Studies, vol. 44, no. 4, pp. 686-703, 1996.

[111] R. Jewkes, M. Flood, and J. Lang, "From work with men and boys to changes of social norms and reduction of inequities in gender relations: a conceptual shift in prevention of violence against women and girls," The Lancet, vol. 385, no. 9977, pp. 1580-1589, 2015.

[112] R. B. Olsen, L. L. Orr, S. H. Bell, and E. A. Stuart, "External validity in policy evaluations that choose sites purposively," Journal of Policy Analysis and Management, vol. 32, no. 1, pp. 107-121, 2013.

[113] United Nations International Strategy for Disaster Risk Reduction, Sendai Framework for Disaster Risk Reduction 2015-2030, United Nations International Strategy for Disaster Risk Reduction, Geneva, Switzerland, 2015.

[114] D. Matyas and M. Pelling, "Positioning resilience for 2015: the role of resistance, incremental adjustment and transformation in disaster risk management policy," Disasters, vol. 39, no. s1, pp. s1-s18, 2015.

[115] W. N. Adger, "Social-ecological resilience to coastal disasters," Science, vol. 309, no. 5737, pp. 1036-1039, 2005.

[116] X. Miao, D. Banister, and Y. Tang, "Embedding resilience in emergency resource management to cope with natural hazards," Natural Hazards, vol. 69, no. 3, pp. 1389-1404, 2013.

[117] E. L. F. Schipper, F. Thomalla, G. Vulturius, M. Davis, and K. Johnson, "Linking disaster risk reduction, climate change and development," International Journal of Disaster Resilience in the Built Environment, vol. 7, no. 2, pp. 216-228, 2016. 